\title{
Uji Toksisitas dengan Menggunakan Metode Brine Shrimp Lethality Test (Bslt) Pada Ekstrak Mangrove (Avicennia Marina, Rhizophora Mucronata, Sonneratia Alba dan Xylocarpus Granatum) yang Berasal dari Banyuasin, Sumatera Selatan
}

\author{
${ }^{1}$ Elsy Puspitasari, ${ }^{1}$ Rozirwan* ${ }^{*}{ }^{1}$ M. Hendri \\ ${ }^{1}$ Program Studi Ilmu Kelautan FMIPA Universitas Sriwijaya, Inderalaya Indonesia \\ *email: rozirwan@unsri.ac.id
}

Diterima: 20 April 2018 Publish: 28 Juni 2018

\begin{abstract}
Abstrak
Mangrove merupakan salah satu sumber senyawa bioaktif yang berasal dari wilayah pesisir dan diketahui memiliki potensi sebagai antikanker. Tujuan penelitian ini adalah untuk menghitung dan menganalisis tingkat toksisitas serta membandingkan kemampuan toksisitas ekstrak daun, batang dan akar mangrove (A. marina, $R$. mucronata, $S$. alba dan $X$. granatum) yang berasal dari Pesisir Banyuasin, Sumatera Selatan. Prosedur penelitian meliputi ; pengambilan dan preparasi sampel, ekstraksi, uji toksisitas dengan metode Brine Shrimp Lethality Test (BSLT) dan analisis data menggunakan Analisa Probit. Hasil penelitian ini menunjukkan terdapat tiga ekstrak yang bersifat toksik dan sembilan ekstrak tidak toksik terhadap larva A. salina. Ekstrak yang bersifat toksik terdapat pada daunditandai dengan nilai $\mathrm{LC}_{50}<1000 \mu \mathrm{g} / \mathrm{mL}$. Ekstrak daun A. marina $403.44 \mu \mathrm{g} / \mathrm{mL}, R$. mucronata $709.7 \mu \mathrm{g} / \mathrm{mL}$ dan $S$. alba $801.75 \mu \mathrm{g} / \mathrm{mL}$. Ekstrak daun A. marina memiliki kemampuan toksisitas lebih kuat dibandingkan dengan ekstrak lainnya.
\end{abstract}

Kata Kunci : Artemia salina, Banyuasin, BSLT, Ekstrak mangrove, Potensi antikanker

\begin{abstract}
Mangrove is one of the bioactive compound sources from coastal area and has known as potential anticancer. The purposes of this study were to calculate and analyze the toxicity level of each mangrove species (Avicennia marina, Rhizophora mucronata, Sonneratia alba and Xylocarpus granatum) and determine the strongest toxicity level among those species. The procedures in this study included; samplescollection and preparation, extraction, toxicity test used Brine Shrimp Lethality Test (BSLT) method and data analyzed Probit Analysis. The results showed that three extracts had the potential toxicity and nine other extracts had no toxicity effect to Artemia salina larvae. The toxic extracts contained in the leaves were characterized by $L C_{50}<1000 \mu \mathrm{g} / \mathrm{mL}$. The leaf extract toxicity of A. marina, R. mucronata and $S$. alba were $403.44 \mu \mathrm{g} / \mathrm{mL}, 709.7$ $\mu \mathrm{g} / \mathrm{mL}$ and $801.75 \mu \mathrm{g} / \mathrm{mL}$, respectively. The A. marina leaf extract had a potential to be the strongest toxic among other extracts
\end{abstract}

Keywords : Artemia salina, Banyuasin, BSLT, Mangrove extract, Potential anticancer 


\section{Pendahuluan}

Akhir - akhir ini pencarian akan sumber kandungan senyawa bioaktif terus menerus dilakukan seiring dengan semakin bertambah banyaknya penyakit - penyakit baru yang bermunculan, seperti penyakit infeksi, kanker dan beberapa penyakit lainnya. Oleh karena itu, dibutuhkan beberapa penelitian tentang kandungan senyawa bioaktif. Senyawa bioaktif dapat berasal dari beberapa sumber, diantaranya dari tumbuhan, hewan, mikroba dan organisme laut lainnya.

Salah satu sumber senyawa bioaktif yang berasal dari tumbuhan adalah mangrove. Mangrove banyak digunakan dikalangan masyarakat khususnya daerah pesisir sebagai obat herbal. Menurut Soetarno (2000) dalam Diastuti et al. (2009)sumber senyawa bioaktif yang dimiliki mangrove diantaranya golongan tanin, saponin, terpenoid, alkaloid dan steroid dengan aktivitas sebagai antimikroba, antifungi, antivirus, antitumor, insektisida dan antileukimia. Bagian tumbuhan yang dapat digunakan sebagai antikanker adalah kulit batang, akar, daun, bunga dan buah.
Beberapa senyawa bioaktif di atas dapat juga ditemukan di berbagai jenis mangrove seperti yang tersebar di daerah pesisir Sumatera Selatan. Tanjung Api-Api, Tanjung Carat dan Pulau Payung merupakan kawasan mangrove yang termasuk ke dalam Kabupaten Banyuasin. Beberapa jenis vegetasi mangrove yang terdapat di daerah ini seperti Avicennia marina, Rhizophora mucronata, Sonneratia alba, Xylocarpus granatum dan lain-lain.

Adapun cara untuk mengetahui suatu tumbuhan memiliki kandungan senyawa bioaktif yang berpotensi sebagai antikanker adalah dengan melakukan penelitian awal. Penelitian ini sebagai indikator awal dalam pengujian sitotoksik. Meyer et al. (1982) mengemukakan bahwa salah satu metode awal untuk uji sitotoksik adalah Brine Shrimp Lethality Test (BSLT).

Uji toksisitas dengan menggunakan metode BSLT dimaksudkan untuk menentukan potensial suatu senyawa sebagai racun dengan mengetahui tingkat toksisitas dari suatu ekstrak, seperti ekstrak mangrove. Fajarningsihet al. 
(2006)menyebutkan bahwa uji toksisitas dengan metode BSLT dapat dilakukan dengan cepat, murah dan mudah, sehingga banyak digunakan sebagai tahapan awal (skrining) dalam penapisan ekstrak bahan aktif.

Penelitian ini bertujuan untuk menghitung dan menganalisis tingkat toksisitas serta membandingkan kemampuan toksisitas ekstrak daun, batang dan akar mangrove (A. marina, R. mucronata, S. alba dan X. granatum) yang berasal dari

II. Bahan dan Metode Waktu dan Tempat

Penelitian ini dilaksanakan pada bulan Juni - September 2016. Sampel mangrove diambil di tiga lokasi berbeda yaitu Kawasan Tanjung Api-Api, Tanjung Carat dan Pulau Payung (Gambar 1.). Perlakuan sampel dan uji toksisitas dilakukan di Laboratorium Bioekologi Kelautan, Program Studi Ilmu Kelautan, FMIPA, Universitas Sriwijaya Inderalaya.

Banyuasin, Sumatera Selatan.

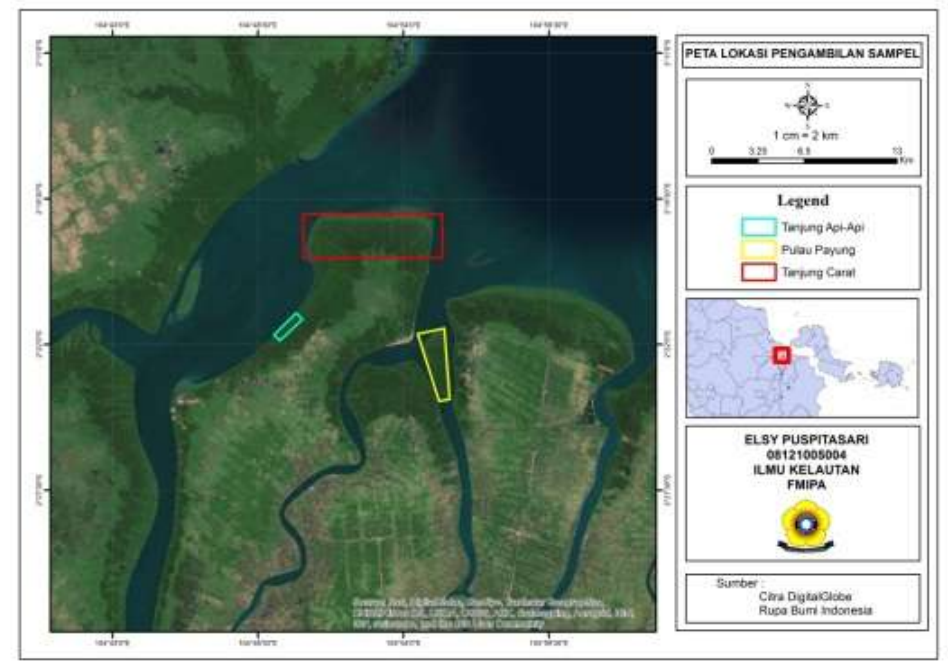

Gambar 1. Peta Lokasi Pengambilan sampel mangrove

\section{Pengambilan dan Preparasi}

\section{Sampel}

Sampel penelitian berasal dari Tanjung Api-Api, Tanjung Carat dan Pulau Payung Sumatera Selatan dan diambil secara acak (random sampling). Bagian - bagian tubuh mangrove meliputi daun, batang dan akar diambil dari pohon yang telah produktif. Sampel dalam keadaan 
segar masing-masing sebanyak \pm 1 $\mathrm{Kg}$ dibersihkan kemudian dipotong tipis-tipis. Selajutnya dikeringkan dengan cara diangin-anginkan sampai kering kemudian dihaluskan dengan grinder dan disaring menggunakan ayakan hingga menjadi bubuk.

\section{Ekstraksi}

Tahapan ekstraksi ini memodifikasi penelitian Rozirwan (2015) yaitu sampel mangrove yang sudah dihaluskan kemudian dimasukkan ke dalam toples kaca besar sebanyak $100 \mathrm{~g}$ dan dimaserasi dalam pelarut metanol $(\mathrm{MeOH})$ $(1: 4, \quad b / v)$ yang sudah didestilasi selama 48 jam pada suhu ruangan dan dilakukan pengulangan sebanyak 3 kali. Larutan hasil maserasi tersebut kemudian disaring dengan menggunakan kertas saring dan vacuum pump, selanjutnya dievaporasi pada suhu $70{ }^{\circ} \mathrm{C}$ sampai menghasilkan pasta yaitu ekstrak kasar (crude extract). Masingmasing ekstrak kasar yang diperoleh dilakukan uji toksisitas menggunakan metode BSLT, yaitu untuk mengetahui tingkat toksisitas dari setiap ekstrak sampel yang ada.

\section{Uji toksistas menggunakan metode BSLT}

Penyiapan larva A. salina Leach

Penyiapan larva merujuk pada penelitian Panggabean (1984) dengan mempertimbangkan beberapa faktor, seperti salinitas $5-70 \mathrm{ppt}$, DO minimal 3 mg/L, pH 8 - 9, suhu $28-35{ }^{\circ} \mathrm{C}$. Penetasan dilakukan menggunakan toples kaca dengan cara merendam $1 \mathrm{~g}$ kista A. salina tersebut dalam air laut sebanyak 100 $\mathrm{mL}$ dan diberi penerangan dengan lampu listrik serta diaerasi selama 48 jam.

Penyiapan Larutan Uji

Penyiapan larutan uji memodifikasi penelitian Diastutiet al. (2009). Konsentrasi awal sebesar $10.000 \mu \mathrm{g} / \mathrm{mL}$ sebagai larutan induk dengan melarutkan $1 \mathrm{~g}$ ekstrak ke dalam $100 \mathrm{~mL}$ air laut. Larutan tersebut selanjutnya dilakukan pengenceran sehingga mendapatkan konsentrasi 9.000, 5.000, 2.000, $1.000,500,250,125$ dan 62,5 $\mu \mathrm{g} / \mathrm{mL}$. Larutan yang digunakan sebagai kontrol dilakukan tanpa penambahan ekstrak.

Uji Toksisitas

Uji toksisitas ini dilakukan dengan memodifikasi penelitian yang 
dilakukan oleh Sangi et al. (2012). Disiapkan tabung vial ukuran $10 \mathrm{~mL}$, kemudian larutan uji masing-masing dipipet diambil dari konsentrasi induk. Selanjutnya ditambahkan air laut dan 10 ekor larva A. salina yang telah berumur 2 hari hingga volumenya mencapai $5 \mathrm{~mL}$. Setiap konsentrasi dilakukan 3 kali pengulangan dan dibandingkan dengan kontrol. Pengujian ini dilakukan selama 24 jam kemudian dilihat jumlah mortalitas larva $A$. salina.

\section{Analisis Data}

Uji toksisitas sampel ditentukan dengan melihat besarnya nilai dari $\mathrm{LC}_{50}$ yang dapat mematikan A. salina sampai $50 \%$ dan dilakukan perhitungan statistik dengan analisa probit (probability unit). Menurut Nurhayati et al. (2006), efek toksisitas dianalisis dari pengamatan denganpersen kematian. $\%$ Mortalitas $=\frac{\text { Jumla } h \text { larva mati }}{\text { Jumla } \text { h larva uji }} \times 100 \%$ Abbott (1925) dalam Meyeret al. (1982) mengatakan apabila pada kontrol terdapat larva yang mati, maka \% kematian ditentukan dengan rumus :

$$
\begin{array}{r}
\% \text { Mortalitas }=\frac{\text { Uji }- \text { Kontrol }}{\text { Kontrol }} \times 100 \% \\
\text { Setelah } \quad \text { mengetahui } \%
\end{array}
$$

Mortalitas larva A. salina, kemudian dicari nilai probit melalui tabel probit dan diregresikan secara linier.

$$
\mathrm{Y}=\mathrm{a}+\mathrm{bX}
$$

Keterangan:

$\mathrm{Y}=$ Nilai probit

$\mathrm{a}=$ Konsentrasi regresi

$\mathrm{b}=$ Slope/kemiringan regresi

$\mathrm{X}=$ Logaritma $_{10}$ konsentrasi uji

Kategori toksisitas pada ekstrak mangrove ditentukan dengan nilai konsentrasi $\mathrm{LC}_{50}$, seperti yang disajikan pada Tabel 1.

Tabel 1.Nilai dan Kategori Toksisitas (Meyer et al., 1982)

\begin{tabular}{ccc}
\hline No & Nilai $\mathrm{LC}_{50}(\mu \mathrm{g} / \mathrm{mL})$ & Kategori Toksisitas \\
\hline 1 & $<1000$ & Toksik \\
2 & $>1000$ & Tidak toksik \\
\hline
\end{tabular}




\section{Hasil dan Pembahasan}

\section{Jenis Mangrove}

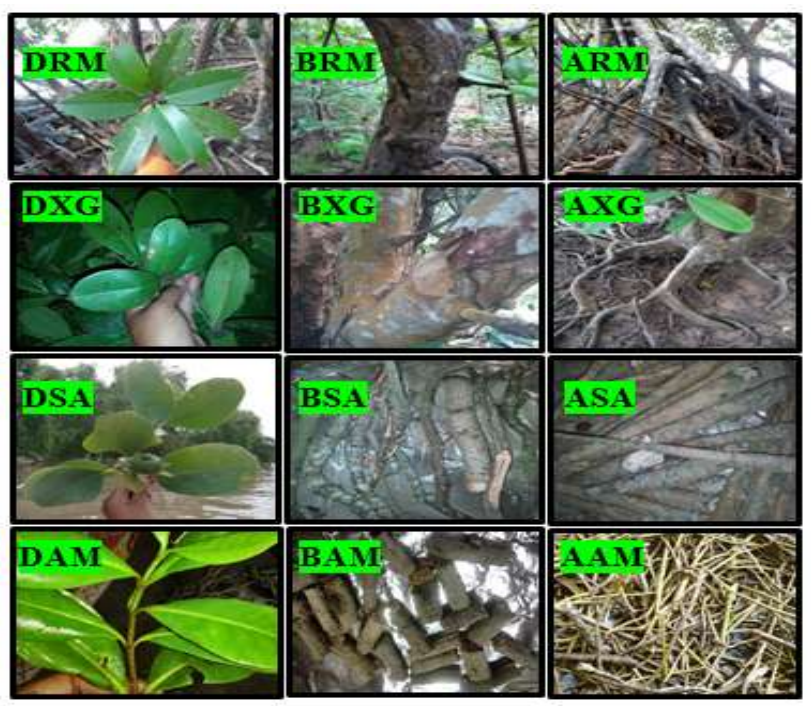

Gambar 2. Jenis sampel mangrove yang diperoleh

Berdasarkan gambar di atas ciri-ciri daun, batang dan akar dari mangrove R.mucronata,X.granatum, S.alba dan A.marinayang diambil di lapangan sesuai dengan deskripsi yang dilakukan oleh Noor et al. (2012).

Tabel 2. Biomassa sampel mangrove

\section{Biomassa Ekstrak Sampel Mangrove}

Biomassa sampel mangrove Penyusutan sampel dari berat basah sampai kering menghasilkan persentase penyusutan pada sampel yang disajikan pada Tabel 2.

\begin{tabular}{|c|c|c|c|c|}
\hline \multirow{2}{*}{ Sampel } & \multirow{2}{*}{ Kodesampel } & \multicolumn{2}{|c|}{ Bobot sampel (Kg) } & \multirow{2}{*}{$\begin{array}{c}\text { Persentase } \\
\text { penyusutan }(\%)\end{array}$} \\
\hline & & Basah & Kering udara & \\
\hline \multirow{3}{*}{ R.muconata } & DRM & 0.75 & 0.40 & 46.67 \\
\hline & BRM & 0.98 & 0.55 & 43.88 \\
\hline & ARM & 1.00 & 0.60 & 40.00 \\
\hline \multirow{3}{*}{ X.granatum } & DXG & 0.60 & 0.20 & 66.67 \\
\hline & BXG & 0.80 & 0.30 & 62.50 \\
\hline & AXG & 0.55 & 0.20 & 63.64 \\
\hline \multirow{3}{*}{ S.alba } & DSA & 1.20 & 0.41 & 65.83 \\
\hline & BSA & 1.10 & 0.58 & 47.27 \\
\hline & ASA & 1.00 & 0.65 & 35.00 \\
\hline \multirow{3}{*}{ A.marina } & DAM & 0.85 & 0.25 & 70.59 \\
\hline & BAM & 0.75 & 0.27 & 64.00 \\
\hline & AAM & 0.60 & 0.20 & 66.67 \\
\hline
\end{tabular}


Berdasarkan Tabel 2. rata-rata persentase penyusutan seluruh bobot sampel yaitu $56.06 \%$ dengan persentase tertinggi $70.59 \%$ dan terendah $\quad 35.00 \quad \%$.Persentase tertinggi didapatkan pada kode sampel DAM yang merupakan daun A.marina dengan bobot sampel basah yaitu $0.85 \mathrm{Kg}$ dan bobot sampel kering $0.25 \mathrm{Kg}$. Persentase terendah terdapat pada kode sampel ASA. ASA merupakan Akar S.alba dengan bobot basah $1.00 \mathrm{Kg}$ dan bobot kering $0.65 \mathrm{Kg}$.

Persentase penyusutan yang dihasilkan dari masing-masing sampel yang dikeringkan dengan cara diangin-anginkan bervariasi pada lama waktu pengeringan dan lokasi tempat pengeringan.
Perbedaan ini diduga disebabkan karena tiap sampel mangrove mempunyai kandungan kadar air yangberbeda-beda. Masduqi et al. (2014)mengatakan bahwa kadar air tersebut dihilangkan dengan cara dikeringkan agar kualitas kandungan dalam sampel semakin baik karena pengeringan ini akan berpengaruh terhadap senyawa penting yang terkandung dalam sampel.

Biomassa ekstrak mangrove

Tahapanmaserasi yang telah dilakukan sebanyak tiga kali pengulangan dengan menggunakan pelarut metanol (polar) dan dilanjutkan dengan tahapan evaporasi, maka didapatkan hasil ekstrak sampel jenis mangrove yang disajikan padaTabel 3.

Tabel 3. Biomassa ekstrak mangrove

\begin{tabular}{lcccc}
\hline \multirow{2}{*}{ Sampel } & Kodesampel & \multicolumn{2}{c}{ Berat ekstrak (gr) } & Persentase (\%) \\
\cline { 3 - 4 } R.muconata & & 100 & 1.43 & \\
& DRM & 100 & 9.10 & 1.43 \\
\multirow{3}{*}{ X.granatum } & BRM & 100 & 9.80 & 9.10 \\
& ARM & 100 & 2.64 & 9.80 \\
\multirow{5}{*}{ S.alba } & DXG & 100 & 4.63 & 2.64 \\
& BXG & 100 & 10.41 & 4.63 \\
\multirow{4}{*}{ A.marina } & AXG & 100 & 3.91 & 10.41 \\
& DSA & 100 & 1.57 & 3.91 \\
& BSA & 100 & 1.89 & 1.57 \\
& ASA & 100 & 6.95 & 6.95 \\
& DAM & 100 & 2.73 & 2.73 \\
& BAM & 100 & 5.14 & 5.14 \\
\hline
\end{tabular}


Berdasarkan Tabel 3. hasil ekstraksi dengan cara merendam 100 gr serbuk sampel menunjukkan bahwa rata-rata ekstrak kasar yang dihasilkan adalah 5.02 gr dengan hasil ekstrak terbanyak AXG yaitu 10.41 gr (10.41 $\%)$ dan paling sedikit DRM yaitu 1.43 gr $(1.43 \%)$. Berat ekstrak kasar untuk jenis mangroveR.mucronata, X.granatum, S. alba dan A. marina secara berurutan paling banyak pada sampel ARM 9.80 gr (9.80 \%), AXG 10.41 gr (10.41\%), DSA 3.91 gr (3.91\%) dan DAM 6.95 gr $(6.95 \%)$. Persentase yang dihasilkan dari masing-masing sampel mangrove dan setiap bagian yang dimaserasi memiliki nilai persentase rendemen yang berbeda pada habitat dan lokasi yang berbeda. Adanya variasi ini diduga disebabkan karena tiap jenis mangrove mempunyai pola adaptasi fisiologi yang berbeda terhadap lingkungannya.
Lebih jelasnya, Murniasih (2005) dalamMelki et al. (2011)menyatakan bahwa senyawa bioaktif yang dihasilkan oleh organisme laut dipengaruhi beberapa faktor diantaranya salinitas, intensitas cahaya matahari, arus dan kompetisi sehingga mendorong organisme laut menghasilkan metabolit sekunder.

Adanya perbedaan rendemen ekstrak yang dihasilkan sesuai dengan pernyataan Salamah et al. (2008)bahwa rendemen ekstrak hasil maserasi dengan pelarut yang berbeda akan menghasilkan persentase rendemen yang berbeda.

\section{Uji Toksisitas Ekstrak}

Tingkat Toksisitas Ekstrak

Uji toksistas yang telah dilakukan yaitu pada ekstrak R.mucronata, X.granatum,A.marina dan S.alba terhadap larva A.salina disajikan pada Tabel 4. 
Tabel 4. Hasil uji toksisitas beberapa ekstrak

\begin{tabular}{|c|c|c|c|c|c|}
\hline \multirow{2}{*}{ Kode sampel } & \multicolumn{3}{|c|}{ Regresi Linier } & \multirow{2}{*}{ Nilai $\mathrm{LC}_{50}(\mu \mathrm{g} / \mathrm{mL})$} & \multirow{2}{*}{ Kategori } \\
\hline & a & $\mathrm{b}$ & $\mathrm{R}^{2}$ & & \\
\hline$\overline{\text { DRM }}$ & -2.066 & 2.4784 & 0.9653 & 709.7 & Toksik \\
\hline BRM & -3.154 & 2.5219 & 0.9679 & 1711.42 & Tidak toksik \\
\hline ARM & -4.41 & 2.9986 & 0.9452 & 1374.03 & Tidak toksik \\
\hline DXG & -0.382 & 1.7176 & 0.9526 & 1360.43 & Tidak toksik \\
\hline BXG & -0.319 & 1.6583 & 0.9455 & 1611.39 & Tidak toksik \\
\hline AXG & 0.9107 & 1.4768 & 0.9522 & 1805.38 & Tidak toksik \\
\hline DAM & -0.989 & 2.2982 & 0.9489 & 403.44 & Toksik \\
\hline BAM & 0.3538 & 1.2103 & 0.9854 & 6900.54 & Tidak toksik \\
\hline AAM & 0.441 & 1.3459 & 0.9798 & 2439.63 & Tidak toksik \\
\hline DSA & 0.382 & 1.5902 & 0.9784 & 801.75 & Toksik \\
\hline BSA & 1.453 & 0.9709 & 0.9849 & 4501.02 & Tidak toksik \\
\hline ASA & -0.205 & 1.468 & 0.972 & 3510.49 & Tidak toksik \\
\hline
\end{tabular}

Berdasarkan Tabel 4. hasil uji toksisitas ekstrak dari ekstrakR.mucronata, X.granatum, A.marina dan S.alba menunjukkan bahwa terdapat 3 ekstrak yang toksik dan 9 ekstrak yang tidak toksik. Ketiga ekstrak tersebut semua berasal dari bagian daun kecuali daun X.granatum (DXG) sedangkan sampel pada bagian yang lainnya tidak menunjukkan sifat toksik. Nilai $\mathrm{LC}_{50}$ dengan kategori toksik pada bagian daun tersebut menunjukkan urutan yang paling kecil pada daun A.Marina(DAM), daun R.Mucronata(DRM), dan daun S.alba(DSA).

Penelitian Diastuti et al. (2009) menunjukkan bahwa senyawa bioaktif yang terkandung dalam daun R.mucronata pada ekstrak etanol dengan fraksi klorofom yaitu mengandung senyawa flavonoid, terpenoid dan alkaloid. Selain itu Bandaranayake (2002) dalamHerawati et al. (2009)menyatakan bahwa pada family Rhizphoraceae banyak ditemukan suatu senyawa polifenol yaitu tanin.

Umumnya komponen utama senyawa tanin adalah fenolik dalam bentuk polimerik fenol yang banyak terdapat pada teh dan tanaman bakau(Purwaningsih et al., 2013). Secara umum, senyawa fenol pada konsentrasi tinggi bertindak sebagai toksin bagi plasma untuk merusak 
sistem dinding sel dan untuk mengumpulkan protein dalam sel, sedangkan pada konsentrasi rendah dapat menghambat multiplikasi enzim in vitro (Ogata et al., 2005 dalam Herawati et al., 2009).

S.alba yang merupakan tumbuhan mengrove yang termasuk kedalam family Sonneratiaceae. Sifat toksik yang dimiliki oleh family Sonneratiaceae ini berasal dari senyawa biokatif yang terkandung di dalamnya seperti tanin. Menurut Bandaranayake (2002) dalam Herawati et al. (2009) mengatakan bahwa tanin merupakan salah satu senyawa polifenol yang banyak ditemukan pada tumbuhan mangrove familyAvicenniaceae, Rhizophoracee, dan Sonneratiaceae.

Ekstrak daun A.marina dapat bersifat toksik karena di dalam ekstrak tersebut mengandung senyawa bioaktif yang bersifat toksik. Bandaranayake (2002) dalam Herawati et al. (2009) menyatakan bahwa pada familiy Avicenniaceae seperti A.marina banyak mengandung senyawa tanin dan pada Avicenniasp juga mengandung senyawa flavonoid dan saponin (Bachtiar, 2010 dalamMulyaniet al., 2013).

Nilai LC $_{50}$ yang tinggi dan bersifat tidak toksik ini dikarenakan rendahnya mortalitas larva $A$. salina konsentrasi < $1000 \mu \mathrm{g} / \mathrm{mL}$, yaitu pada konsentrasi ini mortalitas tidak mencapai sebesar $50 \%$ dari jumlah larva yang ujikan. Selain itu, diduga juga pada ekstrak sampel tidak mengandung senyawa metabolit sekunder atau senyawa pada ekstrak tersebut tidak terdeteksi pada konsentrasi yang diinginkan sehingga bersifat tidak toksik. Suatu senyawa dapat bersifat toksik apabila dalam jangka waktu pendek mampu mematikan $50 \%$ dari larva $A$. salina.

\section{Kemampuan Toksisitas Ekstrak}

Ekstrak - ekstrak tersebut dengan nilai $\mathrm{LC}_{50}$ yang berbeda-beda tentunya memiliki kemampuan toksisitas yang berbeda pula. Secara sederhana kemampuan toksisitas ekstrak dapat dilihat pada Gambar 3. 


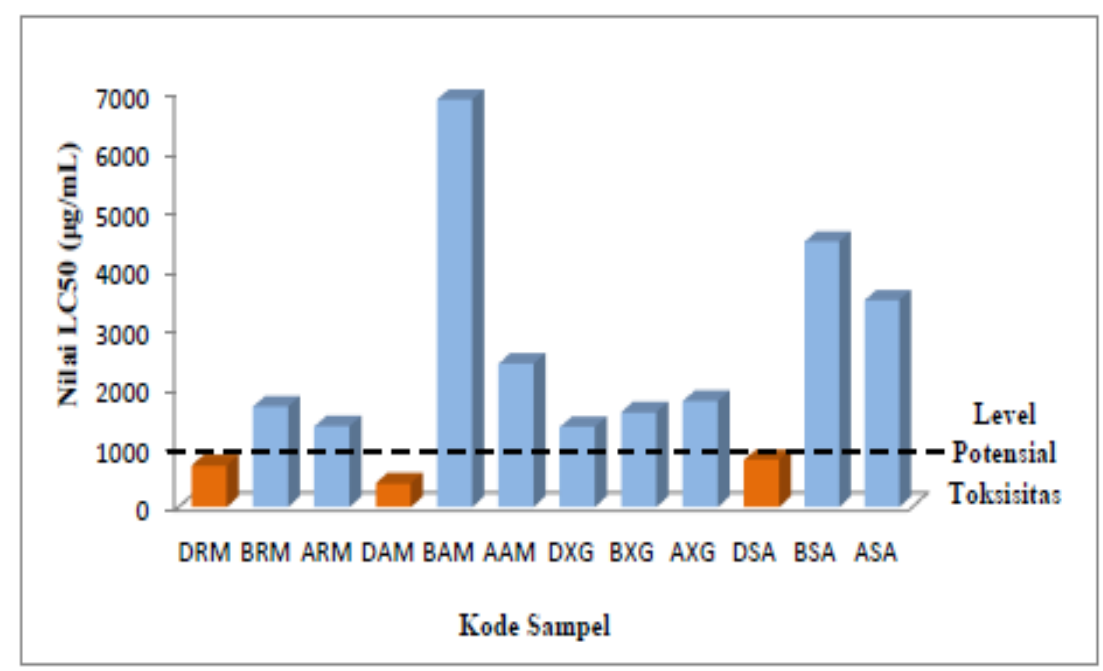

Gambar 3. Kemampuan toksisitas ekstrak

Berdasarkan Gambar 3. nilai $\mathrm{LC}_{50}$ tertinggi terdapat pada ekstrak batang A. marina (BAM) dan terendah yaitu ekstrak daun $A$. marina(DAM). Rendahnya nilai $\mathrm{LC}_{50}$ pada ekstrak daun $A$. marinamembuktikan bahwa ekstrak tersebut memiliki sifat toksik yang lebih kuat dibandingan dengan ekstrakbatang

A. marina (BAM) maupun ekstrak lainnya. Hal ini merujuk pada pernyataan Meyer et al. (1982) apabila nilai $\mathrm{LC}_{50}<1000 \mu \mathrm{g} / \mathrm{mL}$ tersebut besifat toksik dan nilai $\mathrm{LC}_{50}>1000 \mu \mathrm{g} / \mathrm{mL}$ bersifat tidak toksik.

Jacoeb et al. (2011) menyatakan bahwa senyawa aktif yang terkandung dalam daun $A$. marina secara umum bersifat polar. Harbone (1987) dalam Jacoeb et al. (2011) menyebutkan pelarut yang bersifat polar mampu mengekstrak senyawa alkaloid kuartener, komponen fenolik, karotenoid, tanin, gula, asam amino dan glikosida. Beberapa senyawa tersebut diatas diduga memiliki sifat toksik sehingga ekstrak DAM memiliki nilai $\mathrm{LC}_{50}<1000 \mu \mathrm{g} / \mathrm{mL}$.

Beberapa ekstrak mangrove yang bersifat tidak toksik dan memiliki kemampuan toksik yang rendah seperti pada bagian daun, batang dan akar X.granatum, serta batang dan akar A. marina, $R$. mucronata dan S. alba diduga bahwa pada ekstrak ini tidak mengandung senyawa bioaktif yang bersifat racun. 
Namun lebih jelasnya, Satari

(1997) dalamMelkiet al. (2011) mengemukakan bahwa ekstrak yang kecil bahkan tidak ada aktivitas senyawa bioaktif belumlah berarti ekstraknya tidak aktif, tetapi kemungkinan tidak terdeteksi pada konsentrasi yang diuji atau konsentrasi yang digunakan umumnya belum tercapai.

\section{Kesimpulan}

1. Terdapat sembilan ekstrak sampel yang tidak toksik dan tiga ekstrak sampel yang bersifat toksik dengan memiliki nilai $\mathrm{LC}_{50}<1000$ $\mu \mathrm{g} / \mathrm{mL}$ yaitu ekstrak daun $A$. marina (DAM) 403,44 $\mu \mathrm{g} / \mathrm{mL}, R$. mucronata (DRM) 709,7 $\mu \mathrm{g} / \mathrm{mL}$ dan S. alba (DSA) $801,75 \mu \mathrm{g} / \mathrm{mL}$.

2. Kemampuan toksisitas ekstrak dari daun A. marina (DAM) memiliki sifat toksik lebih kuat dibandingkan dengan ekstrak lainnya.

\section{Daftar Pustaka}

Diastuti H, Warsinah, Purwati. 2009. Uji aktivitas antikanker ekstrak etanol daun Rhizoporamucronata terhadap larva udang Artemia salina Leach dan Sel Raji. Jurnal Molekul 4 (1): 12-20
Fajarningsih ND, Januar HI, Nursid M, Wikanta T. 2006. Potensi antitumor ekstrak spons Crella papilata asal Taman Nasional Laut Kepulauan Seribu. Jurnal Pascapanen dan Bioteknologi Kelautan dan Perikanan. 1(1): 35-42

Herawati N, Jalaluddin N, Daha L, Firdaus Z. 2009. Sonneratia alba sebagai sumber senyawa antibakteri potensional. Jurnal Indonesia Chemica Acta. 2(2): 10-16

Jacoeb AM, Purwaningsih S, Rinto. 2011. Anatomi, komponen bioaktif dan aktivitas antioksidan daun mangrove api-api (Avicennia marina). Jurnal Pengolahan Hasil Perikanan Indonesia. 14(2)

Masduqi AF, Izzati M, Prihastanti E. 2014. Efek metode pengeringan terhadap kandungan bahan kimia dalam rumput laut Sargassumpolycystum. Jurnal Anatomi Fisiologi. 22(1): 1-9

Melki, Soedharma D, Effendi H, Mustopa AZ. 2011. Biopotensi tumbuhan mangrove untuk pencegahan penyakit vibrosis pada udang windu. Maspari Journal. 2(1): 39-47

Meyer BN, Ferrigni NR, Putnam JE, Jacobsen LB, Nichols Dj, McLaughlin JL. 1982. Brine shrimp: A convenient general bioassay for active plant constituents. Planta medica. (45): 31-34 
Mulyani Y, Bachtiar E, Agung MUK. 2013. Peranan senyawa metabolit sekunder tumbuhan mangrove terhadap infeksi bakteri Aeromonas hydrophila pada ikan Mas (Cyprinus carpio L.). Jurnal Akuatika. 4(1): 1-9

Noor YR, Khazali M, Suryadiputra INN. 2012. Panduan Pengenalan Mangrove di Indonesia. Bogor: Wetlands International Indonesia Programe

Nurhayati APD, Abdulgani N, Febrianto R. 2006. Uji toksisitas ekstrak Eucheuma alvarezii terhadap Artemia salina sebagai studi pendahuluan potensi anti kanker. Akta Kimindo. 2(1): 41-46

Panggabean MGL. 1984. Teknik penetasan dan pemanenan Artemia salina. Jurnal Oseana. IX(2): 57-65

Purwaningsih S, Sukarno AYP, Deskawati E, Salamah E. 2013. Aktivitas Antioksidan dari buah mangrove (Rhizophora mucronata Lamk.) pada suhu yang berbeda. JPHP. 16 (3): 200206

Rozirwan. 2015. Eksplorasi spasial karang lunak kaitannya dengan senyawa bioaktif bakteri simbion [disertasi]. Bogor: IPB

Salamah E, Ayuningrat E, Purwaningsih S. 2008. Penapisan awal komponen bioaktif dari Kijing Taiwan (Anadonta woodiana Lea.) sebagai senyawa antioksidan. Buletin Teknologi Hasil Perikanan. 11(2): 119-132

Sangi MS, Momuat LI, Kumaunang M. 2012. Uji toksisitas dan skrining fitokimia tepung gabah pelepah aren (Arenga pinnata). Jurnal Ilmiah Sains. 12(2): 127-13 